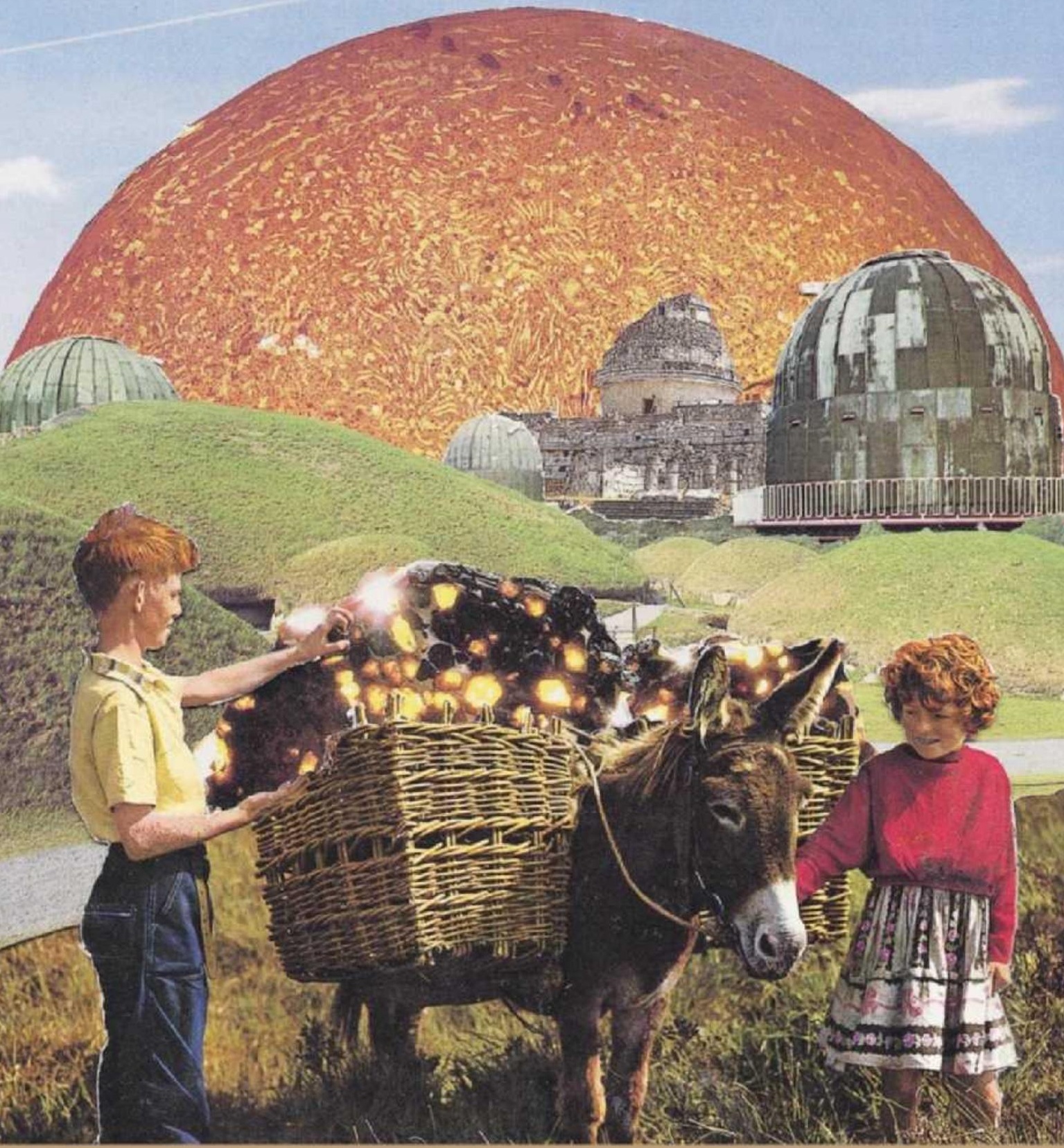

\title{
Irish literature since 1990
}

Diverse voices 


\section{Irish literature since 1990}

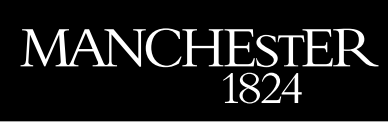

Manchester University Press 
Scott Brewster and Michael Parker - 9781526125149 Downloaded from manchesterhive.com at 04/26/2023 09:32:31AM via free access 


\section{Irish literature since 1990 Diverse voices}

edited by Scott Brewster and Michael Parker

Manchester University Press

Manchester and New York

distributed in the United States exclusively

by Palgrave Macmillan 
Copyright (C) Manchester University Press 2009

While copyright in the volume as a whole is vested in Manchester University Press, copyright in individual chapters belongs to their respective authors.

This electronic version has been made freely available under a Creative Commons (CC-BYNC-ND) licence, which permits non-commercial use, distribution and reproduction provided the author(s) and Manchester University Press are fully cited and no modifications or adaptations are made. Details of the licence can be viewed at https://creativecommons.org/licenses/by-nc-nd/3.0/

Published by Manchester University Press Oxford Road, Manchester M13 9NR, UK and Room 400, 175 Fifth Avenue, New York, NY 10010, USA www.manchesteruniversitypress.co.uk

British Library Cataloguing-in-Publication Data

A catalogue record for this book is available from the British Library

Library of Congress Cataloging-in-Publication Data applied for

ISBN 9780719075636 hardback

First published 2009

$\begin{array}{lllllllllllllllllll}18 & 17 & 16 & 15 & 14 & 13 & 12 & 11 & 10 & 09 & 10 & 9 & 8 & 7 & 6 & 5 & 4 & 3 & 2\end{array}$

Typeset

by Graphicraft Limited, Hong Kong 